\title{
Investigation of The Effect of Turkish Tv Series Watched by Arab Tourists on Their Preference for Visiting Turkey
}

\author{
Arap Turistlerin Türkiye’ye Gelme Sebeplerinde İzledikleri Türk Dizilerinin Etkilerinin Incelenmesi
}

\author{
Nurcan ÖZDEMIR \\ Ministry of Education \\ nurcanegelara@gmail.com \\ https://orcid.org/0000-0001-8198-4600
}

$\begin{array}{ll}\text { Received } & : 28.03 .2021 \\ \text { Revised } & : 02.05 .2021 \\ \text { Accepted } & : 17.12 .2021 \\ \text { Type of Article } & \text { : Research }\end{array}$

\section{ABSTRACT}

\section{Keywords:}

Turkish series,

Arab Tourists,

Soft Power,

Image of Turkey

\section{Anahtar Kelimeler:}

Türk Dizileri,

Arap Turistler,

Yumuşak Güç,

Türkiye imaj1

\section{ÖZET}

Turkish TV series are broadcast in many continents from the Middle East to the Balkans, Africa to Central Asia, the Far East and South America, and are watched by 700 million people in about 156 countries. In this respect, $T V$ series have become one of the effective soft power tools of Turkey in different parts of the world. The adventure of Turkish TV series to conquer the world is an important issue that increases the material and moral gains of Turkey day by day, and thus they should be prioritized. In this study, it was aimed to determine the effect of the Arab people's attitude towards Turkish series and their perception of the image of the on their preference for visiting Turkey. It is a known fact that TV series and movies have the power to direct the and create awareness. In the current study, Turkey was evaluated as a rising soft power that can play an active role in the regional and global arena through its various soft power sources such as its culture, values, foreign policy and economic success, and the effects of Turkish TV series on Arab people and especially the effects of their attitudes towards the TV series and perceptions of the image of the country on their preference for visiting the country were aimed to be examined. To this end, a survey was conducted on 500 Arabs who came to Turkey for touristic purposes. As a result of the analyses, a statistically significant positive relationship was determined between the attitudes towards Turkish TV series and Turkey's image and the effect of Turkish TV series on the participants' preference for visiting Turkey. In addition, Arab tourists' attitudes towards TV series and their perception of the image of Turkey were found to be varying significantly depending on some demographics.

Türk Yapımı Televizyon dizileri Orta Doğu'dan Balkanlar'a, Afrika'dan Orta Asya'ya, Uzak Doğu'dan ve Güney Amerika'ya kadar pek çok kitada yayınlanmakta ve yaklaşık 156 ülkede 700 milyon kişi tarafindan izlenmektedir. Bu yönüyle diziler Türkiye'nin dünyanın farklı coğrafyalarındaki etkili yumuşak güç araçlarından biri haline gelmektedir. Türk dizilerinin dünyayı fethetme serüveni, Türkiye'nin maddi manevi kazanımlarını günden güne artıran ve önemsenmesi gereken mühim bir konudur. Bu çalışmada Arap halkının Türk dizilerine karşı tutumunun ve Türkiye imaj algısının Türkiye'yi ziyaret etmelerindeki etkisinin tespit edilmesi amaçlanmıştır. Dizi ve filmlerin toplumları yönlendirme ve farkındalı yaratma gücü bilinen bir gerçektir. Bu çalışmada, Türkiye, kültürü, değerleri, dış politikası ve ekonomik başarısı gibi çeşitli yumuşak güç kaynakları nedeniyle bölgesel ve küresel alanda aktif rol oynayabilecek yükselen bir yumuşak güç olarak değerlendirilmiş ve Türk dizilerinin Arap halkı üzerindeki etkileri ve özellikle dizilere karşı tutumun ve ülkeye karşı oluşan algının Arap halkının Türkiye yi ziyaret etmesindeki etkileri incelenmiştir. Bu amaçla araştırma Türkiye'ye turistlik amaçla gelmiş 500 Arap üzerinde bir anket uygulanmıştır. Yapılan analizler sonucunda Türk dizilerine yönelik tutum ile Türkiye imajl, Türk dizilerinin Türkiye' yi ziyaret etme etkisi arasında pozitif ve istatistiksel olarak anlamlı bir ilişki tespit edilmiştir. Ayrıca Arap turistlerin demografik özelliklere göre Türk dizilerine karşı tutum ve Türkiye imaj algısı farklılaştığı belirlenmiştir. 


\section{INTRODUCTION}

During the 2000s, series and films produced in Turkey started to be exported to the Arab world, which led to changing perception of Turkey among Arab people, increasing interest in Turkey, Arab people's increasing questioning of their social structure, reduction of the political gap between the Middle East geography and Turkey and re-interpretation of the elements of Turkish foreign policy. Turkey's foreign policy approaches gaining the sympathy of Arab people recently and increasing interest in Turkish TV series motivated Arab people to visit Turkey for touristic purposes (Dinçer and Kutlay, 2012).

The power of TV series and movies to direct societies and create awareness is known (Zavalsız and Soydaş-Dağc1, 2019). Initially, the importance of this power was not taken into consideration in the export of Turkish TV series and movies to the Middle East, but later on, Turkish politicians realized that this export sector would yield significant gains for Turkey in bilateral political relations both globally and regionally (Budak, 2019: 148).

The international dissemination of Turkish television series took place rapidly in a short time between 2005 and 2011. The total number of hours of television series and movies exported to 76 countries is 36,000 . Up to 2015, more than 100 Turkish series were exported to 80 countries (Yeşil, 2015). Turkish TV series have been exported to different cultures such as the Middle East, Balkans, Russia, Africa, Europe and Latin America (Kantarc1, Başaran and Özyurt, 2015). Approximately 6\% of these dramas are broadcast on Middle Eastern and North African Arab televisions (Yanardağoğlu and Karam, 2013). The broadcasting of Turkish series in the Middle East and North African countries was started by the manager of the MBC media company who happened to watch a Turkish TV series in a hotel room in Turkey while he was on holiday. Since then, MBC has been buying Turkish TV series (Alankuş and Yanardağoğlu, 2016). In 2010, the rate of those who watched Turkish TV series in Arab countries is $78 \%$, and it was the highest in Iraq and Syria (Yoruk and Vatikiotis, 2013).

With Turkish series, Turkey aimed to take Arab people under its influence by using its fourth power effectively (Öztürk and Atik, 2016: 68-69). This was thought to make positive contributions to the promotion of Turkey, its export revenues, tourism income, house sales, the emergence of new holiday destinations, accordingly to its economy (Nuroğlu, 2013; Yılmaz, 2014: 31; Aslan, 2019: 33).

There are many reasons why Arabs like Turkish TV series so much. The physical attraction of the actors, natural landscapes with colours of green and blue, romance, emotional scenarios, quality productions, natural acting, historical and modern attractive places and music can be counted among these reasons (TÜROB, 2018). In addition, this popularity of Turkish series can also be related to the fact that the people of the Middle East find the closeness that cannot be found in Brazilian and American TV series in Turkish TV series (Pinto, 2012), that they can see that one can be both Muslim and modern, and to the elements such as common culture, history, language and religion (Deniz, 2010: 61).

The first Turkish TV series export to Kazakhstan started in 2001 with the Deli Yürek series (Öztürk and Atik, 2016: 74), but the Gümüss series is known as the first series to be exported mostly because of its incredible popularity in the market (Deniz, 2010: 51). This continued in 2008 with the export of the Bin Bir Gece series to Bulgaria (Ökmen and Göksu, 2019) and the Gümüşs series to the Middle East (Deniz, 2010: 51).

Through the influence of the Gümü̧s series, İstabul became a popular destination for Arab tourists and the number of Syrian tourists increased from 41,000 in 2007 to 100,000 in 2008. Through the influence of the Gümüş series, the rate of tourists coming from Arab countries and Israel to Turkey increased by $56 \%$ in the first six months of 2011 and up to 2011, the number of tourists visiting the mansion where the series was filmed by paying a $\$ 50$ entry fee was 30,000 (Akdu and Akın, 2016).

The popularity gained by the Gümüş series was far beyond the expectations, the series' finale was watched by 85 million people in the Arab world and the Ihlamurlar Altinda series reached 67 million Arab viewers and all these developments caused the Turkish TV series industry to attach special importance of Arab market. Today, 75 Turkish TV series are broadcast on more than 40 Arab TV channels. These series provided more effective publicity than the advertisements that could have been made possible by paying too much money. Historical samples of Ottoman heritage and beautiful sceneries of İstanbul shown in these series increase Arab people's interest in Turkey (Dinçer and Kutlay, 2012). The momentum gathered by the unexpected success of the Gümüş series, broadcast with the name of Noor in the Middle East, resulted in Turkey's being the second in the series export market after America in the world today (Öztürk and Atik, 2016: 74).

In this connection, the purpose of the current study is to determine the effect of the Arab people's attitude towards Turkish series and their perception of the image of the Turkey on their preference for visiting Turkey. In addition, it is also aimed to investigate whether Arab tourists' attitudes towards Turkey and the perception of the image of Turkey vary significantly depending on some demographic variables (gender, age, income, education and marital status). To this end, a survey study was conducted on 500 Arabs who came to Turkey for touristic purposes. 


\section{LITERATURE REVIEW}

Turkey started to sell its TV series to foreign countries in 2001. The export of TV series has increased in recent years and Turkish TV series have begun to reach a large audience in the Middle East and the Balkans. This has made positive contributions to international viewers' perception of the image of Turkey (Brljavac, 2011) and positively affected their opinions about Turkey (Öktem, 2010). The growing popularity of Turkish television series in the Middle East and the Balkans has been observed to lead to increases in trade and tourism revenues from the countries in these regions to which Turkish TV series have been exported (Balli, Balli and Cebeci, 2013). It is widely accepted that the general consumption of television series tends to increase and that they are an effective tool of promotion (Pervan and Martin, 2002; Miller, 1995).

The study conducted by Deniz (2010) is one of the first studies in the literature on the subject. Deniz (2010) examined the sociological effects of the Gümüss series in particular and Turkish TV series in general in social media environments. According to Deniz, Turkey should consider this process as a means of achieving global and regional achievements within the context of soft power taking into consideration its political and economic effects.

Akova (2014) used the sample of Serbia, Montenegro and Bosnia and Herzegovina. The aim of the study was to contribute to the literature on intercultural communication by examining the concepts of TV series, diplomacy and tourism. Reception technique was used in the study; face-to-face interview and in-depth analysis techniques were also used. From the study, it was concluded that Turkish TV series served as a constructive mortar in Balkan countries, assumed the role of cultural ambassadors between Turkish culture and Balkan culture and strengthened the existing intercultural communication (Akova, 2014).

Matar (2017) examined how Turkish series affected Arab viewers in terms of their intention to visit Turkey. In this qualitative study, in-depth interviews were conducted with Arab tourists visiting Turkey (30 people). Findings showed that TV series are critical in destination marketing and play a role in increasing the number of tourists.

Temina (2019) investigated the effect of Turkish series on the society, particularly the effect of Turkish series watched in Algeria on the Algerians' perception of Turkey, and the effect of TV series on the society and family, religion and socio-cultural issues. In the study, the questionnaire method was used to collect the data. From the study, it was concluded that Algerians who watched Turkish TV series in general admired the TV series because they found sections of their own lives in these series (Temina, 2019).

In the study conducted by Yukarı, Veyseller, Öykü, and İyigün (2018), it was aimed to evaluate the favourite series of Muhteşem Yüzyll, which was mostly exported to the Middle East and watched with appreciation, in terms of destination preference. The primary data of the study were collected through semi-structured in-depth interviews with tourists from the Middle East. This study was conducted with 10 tourists from 5 Middle Eastern countries (Saudi Arabia, UAE, Bahrain, Oman and Qatar) to elicit their opinions only on the Muhteşem Yüzyll series. In the study, it was concluded that the cultural traces and similarities such as intercultural common words, common meals and common customs and traditions attract Arab tourists.

In the study conducted by Akşen (2016), the reasons for which Turkish TV series and actors are named phenomena by the Arab people have been examined in the example of Gümüss. In the study, some social findings were obtained from the analysis of the Gümüş TV series, which was watched with great admiration in the Arab world, and the results were evaluated. The study took the TV series as the unit of analysis and the Gümüş TV series as the universe. The reason why this TV series became so popular is thought to be the longing of Arab women for freedom and their seeing secular Turkey as the guarantor of freedom.

In the study conducted by Akdu and Akın (2016), it was aimed to examine the effects of films on consumers' destination preferences and to present suggestions in this regard. When the results of the study are examined, it is seen that $35.5 \%$ of the participants stated that they visited the country to see and experience the locations and cultural values shown in the series, $26.3 \%$ stated that they visited the country to see the natural beauties shown in the series and $23.9 \%$ stated that they visited the country to see the historical places shown in the series.

Geçer (2015) conducted a study to make socio-cultural evaluations on the basis of the series produced in Turkey. The study investigated the popular culture interactions brought about by the increasing number of made-in-Turkey series shown in Turkish TV channels nationally and internationally and claimed to cause a cultural transformation and cultural emphases shaping these interactions based on the discussions made about the series together with a literature review.

The study conducted by Ozturk and Waste (2016) took the series as its subject of investigation as one of the most important reflections of the global market policies put into effect in Turkey and of the growth observed in the 
media sector in the 2000s. Three of each 4 Turkish series filmed were exported to 103 countries and it was estimated that the series reached 400 million viewers. Thus, it was concluded that after America, Turkey is the country exporting the highest number of series to the world.

Yigit (2013) stated that with TV series considered to be one of the cornerstones of soft power, Turkey has become successful in introducing modern Turkey to the world and that actors and actresses from Turkish series have been used to promote export from other sectors to the Middle East. The most important outcome of this popularity of Turkish series in the Arab world is the perception of Turkey as a modern country by Arab people. Other concrete outcomes are Arab people's increasing interest in Turkish culture and language and the increasing number of Arab tourists visiting Turkey.

\section{METHOD}

In the section, the research model, population, sample and data collection tools used in the current study, validity and reliability studies and the statistical methods used in the analysis of the collected data are presented.

\subsection{Research Model}

In this quantitative study, the data were objectively revealed and analysed. The current study is a correlational study employing the questionnaire technique to collect data. The relational survey model aiming to determine the presence and degree of the relationship between the variables was used in the current study. The correlation method was also used to determine whether the variables of the study showed a consistent covariance.

\subsection{Population and Sample}

The population of the current study is comprised of the Arab tourists coming to Turkey to visit İstanbul and Antalya. The data were collected through the face-to-face administration of the data collection tool. The data collection was presented to the participants tool and they were asked to respond to it on a volunteer basis. The questionnaire was administered to tourists at Antalya and İstanbul and Sabia Gökçen Airports and the Arab tourists staying in the Dedeman Hotel (with the assistance of the personnel) and the questionnaire was also administered to tourists at Sultanahmet square, Gülhane, Eminönü, Maiden's Tower, Çamlıca hill and in Cevahir shopping mall.

According to the data issued by TÜIK (Turkish Statistical Institute), 200 thousand Arab tourists visit Turkey on average every year. These 200 thousand Arab tourists constitute the population of the current study. From among these 200 thousand tourists, a total of 500 tourists coming to visit İstanbul and Antalya were selected by means of the random sampling method. When calculated considering the population size of 200 thousand and the sample size of 500, the error margin resulting from the sample of the study was found to be $4.38 \%$ at the $95 \%$ confidence level.

\subsection{Data Collection Tools}

The data of the current study were collected by means of the questionnaire technique. In the current study, a total of two scales called the Image of Turkey and The Effect of Turkish Series were used. The first scale (The Image of Turkey) was developed by Aliyev (2014). The second scale (The Effect of Turkish Series) was developed by Örgün (2012). The required permissions were obtained from the authors to use these scales. The validity and reliability studies of the scales had already been conducted by the authors.

The questionnaire used in the current study was first prepared in Turkish. Then it was translated into Arabic by an official translator of Syrian origin registered to the $2^{\text {nd }}$ Notary Public in the city of Malatya with the name of Baraa Rihavi. After the necessary controls were conducted on the questionnaire, it was administered to Arab tourists.

The questionnaire used in the current study consists of four parts. In the first part of the questionnaire, there is the personal information form developed by the researcher to elicit some demographics of the participants such as age, marital status, education level, gender and income level. In the second part of the questionnaire, there is the 8-item Turkish Series Attitude Scale; in the third part, there is the 8-item Scale of the Effect of Turkish Series on a visit to Turkey. These two scales were adapted from the scales developed by Abisheva (2019). In the fourth part of the questionnaire, there is the 21-item the Image of Turkey Scale adapted to Turkish by Aliyev (2014). 


\subsection{Data Collection}

First, the necessary permissions were obtained to use the scales in the current study and then the questionnaire form was face-to-face administered to the participants within a two-month period and thus, the data of the study were collected. In order to collect demographic information of the participants, the personal information form developed by the researchers was used. The participation in the study was voluntary and no incentive was offered to the participants in return for their participation. No information about the identity of the participants was requested and it took the participants 5-10 minutes to complete the questionnaire. The protection of the obtained data for two years in compliance with the principles of confidentiality and ethics will be under the responsibility of the researcher.

\subsection{Data Analysis}

First, the responses of the participants to the scales were examined and the scales observed to be incomplete or erroneous were discarded from the analysis. Moreover, the scales of the respondents who were found to have responded insincerely or without even reading the items in the scales were excluded from the analysis. As a result, the data obtained from the questionnaires of 19 respondents were found to be unsuitable for analysis and thus excluded from the study. As some of the participants found the items in the questionnaire discomforting, they did not want to complete the scales and correspondingly the data of 8 participants were excluded from the study. As a result, the data collected from 500 participants were found to meet the criteria of analyzability and thus the analyses of the study were conducted on the data obtained from 500 participants.

The data in the current study were collected by means of the questionnaire method. The questionnaires were administered to the participants face-to-face. In the analysis of the collected data, SPSS 22.00 program package was used. In the study, first, the demographic information of the participants is presented. Then, the reliability calculations of the three scales used in the study are given. In order to determine whether the data distributed normally, Kurtosis and skewness values were calculated. After it was determined that the data distributed normally, ANOVA and t-test were run to determine whether the variables varied significantly depending on the demographic variables. Pearson correlation and regression methods were used to determine the interaction between the variables.

\subsection{Research Model and Hypotheses}

In the current study, the following model was developed to determine the effect of the attitudes towards Turkish series and the perception of the image of Turkey on Arab tourists' preference for visiting Turkey:

Figure 1. Research Model

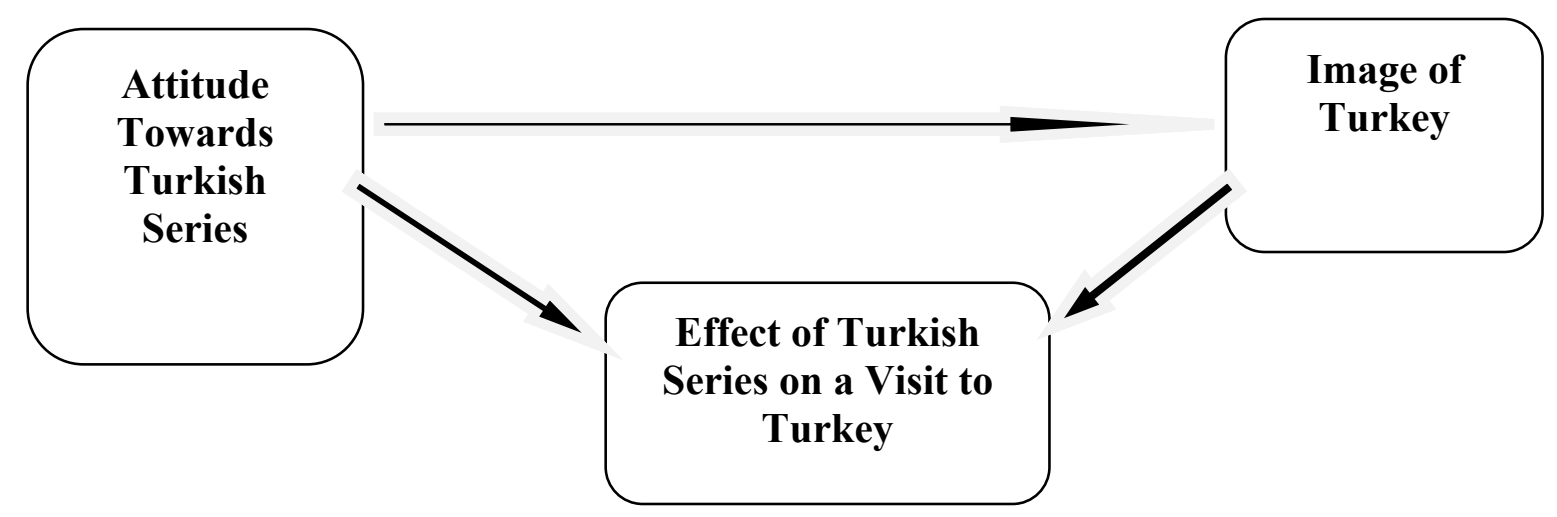

- $H_{1}=$ Arab people's perception of the image of Turkey has a significant effect on their preference for visiting Turkey.

- $\mathrm{H}_{2}=$ Arab people's attitudes towards Turkish series has a significant effect on their preference for visiting Turkey.

- $H_{3}=$ There is a significant correlation between Arab people's attitudes towards Turkish series and perception of the image of Turkey.

- $H_{4}=$ Arab people' attitudes towards Turkish series and perception of the image of Turkey vary significantly depending on gender.

- $H_{5}=$ Arab people' attitudes towards Turkish series and perception of the image of Turkey vary 
significantly depending on marital status.

- $H_{6}=$ Arab people' attitudes towards Turkish series and perception of the image of Turkey vary significantly depending on age.

- $H_{7}=$ Arab people' attitudes towards Turkish series and perception of the image of Turkey vary significantly depending on education level.

- $H_{8}=$ Arab people' attitudes towards Turkish series and perception of the image of Turkey vary significantly depending on income level.

- $H_{9}=$ Arab people' attitudes towards Turkish series and perception of the image of Turkey vary significantly depending on whether having visited Turkey before.

- $H_{10}=$ Arab people' attitudes towards Turkish series and perception of the image of Turkey vary significantly depending on whether they follow the Turkish series.

- $H_{11}=$ Arab people' attitudes towards Turkish series and perception of the image of Turkey vary significantly depending on whether they follow actors and actresses having appeared in Turkish series in social media.

\section{FINDINGS}

In this section of the study, the results of the reliability analysis of the scales and the results of ANOVA and t-test conducted to determine whether the participants' scores taken from the Image of Turkey Scale, the Turkish Series Attitude Scale and the Scale of the Effect of Turkish Series on a visit to Turkey vary significantly depending on the demographic variables are presented. Moreover, the results of the regression and correlation analyses conducted to determine the correlations between the Image of Turkey Scale, the Turkish Series Attitude Scale and the Scale of the Effect of Turkish Series on a visit to Turkey are also presented.

\subsection{Demographic Features of the Participants}

In this section of the study, the demographic features of the participating Arab tourists and the data about the frequency of their having visited Turkey and having watched Turkish series before are presented.

Table 1. Demographic Features of the Participants

\begin{tabular}{|c|c|c|c|}
\hline & Variables & $\mathbf{N}$ & $\%$ \\
\hline \multirow{2}{*}{ Gender } & Female & 248 & 49.6 \\
\hline & Male & 252 & 50.4 \\
\hline \multirow{4}{*}{ Age } & $18-25$ & 141 & 28.2 \\
\hline & $26-35$ & 156 & 31.2 \\
\hline & $36-50$ & 119 & 23.8 \\
\hline & 51 and older & 84 & 16.8 \\
\hline \multirow{4}{*}{ Income Level } & $1000 \$$ and less & 128 & 25.6 \\
\hline & $1001-2000 \$$ & 122 & 24.4 \\
\hline & $2001-3000 \$$ & 186 & 37.2 \\
\hline & $3001 \$$ and more & 64 & 12.8 \\
\hline \multirow{4}{*}{ Education Level } & $\begin{array}{c}\text { Elementary education and } \\
\text { lower }\end{array}$ & 56 & 11.2 \\
\hline & High school & 149 & 29.8 \\
\hline & Associate's degree & 100 & 20.0 \\
\hline & $\begin{array}{c}\text { Undergraduate or graduate } \\
\text { degree }\end{array}$ & 195 & 39.0 \\
\hline \multirow{2}{*}{ Marital Status } & Married & 301 & 60.2 \\
\hline & Single & 199 & 39.8 \\
\hline
\end{tabular}

In Table 1, demographic information of the participants is presented. Nearly half of the participants are females and $60 \%$ of them are married. Moreover, $31.2 \%$ of the Arab tourists are in the age group of $26-35,37.2 \%$ have income ranging from 2001 to $3000 \$$ and $39 \%$ have undergraduate or graduate degree. 
Table 2. Information about the Participants' Attitudes towards Turkish Series

\begin{tabular}{|c|c|c|c|}
\hline & Variables & $\mathrm{N}$ & $\%$ \\
\hline \multirow{4}{*}{$\begin{array}{c}\text { Have you ever been to Turkey } \\
\text { before? }\end{array}$} & First time & 222 & 44.4 \\
\hline & Second time & 104 & 20.8 \\
\hline & Third time & 84 & 16.8 \\
\hline & Fourth time or more & 90 & 18.0 \\
\hline \multirow{5}{*}{$\begin{array}{l}\text { What is your frequency of } \\
\text { watching Turkish TV series? }\end{array}$} & Never & 150 & 30.0 \\
\hline & Once a month & 79 & 15.8 \\
\hline & Once a week & 147 & 29.4 \\
\hline & More than once a week & 59 & 11.8 \\
\hline & Everyday & 65 & 13.0 \\
\hline \multirow{5}{*}{$\begin{array}{l}\text { How many Turkish series have } \\
\text { you watched from the } \\
\text { beginning to the end? }\end{array}$} & None & 121 & 24.2 \\
\hline & 1 & 91 & 18.2 \\
\hline & 2 & 95 & 19.0 \\
\hline & 3 & 61 & 12.2 \\
\hline & 4 and more & 132 & 26.4 \\
\hline \multirow{4}{*}{$\begin{array}{l}\text { What is your reason for } \\
\text { visiting? }\end{array}$} & Touristic & 426 & 85.2 \\
\hline & Business & 24 & 4.8 \\
\hline & Education & 37 & 7.4 \\
\hline & Others & 13 & 2.6 \\
\hline \multirow{2}{*}{$\begin{array}{l}\text { Do you follow actors and } \\
\text { actresses having appeared in } \\
\text { Turkish series in social media? }\end{array}$} & Yes & 122 & 24.4 \\
\hline & No & 378 & 75.6 \\
\hline
\end{tabular}

In Table 2, information about the participants' attitudes towards Turkish series is given. The great majority of the participants have visited Turkey for touristic purposes and do not follow the actors or actresses having appeared in Turkish series on social media. Moreover, $44.4 \%$ of the Arab tourists have been to Turkey for the first time and $30 \%$ of them have never watched Turkish TV series. On the other hand, $26.4 \%$ of the participants have watched 4 or more Turkish series from the beginning to the end.

\subsection{Reliability and Normality Tests}

In this section of the study, the results of the reliability and normality tests of the Scale of Image of Turkey, the Turkish Series Attitude Scale and the Scale of the Effect of Turkish Series on a visit to Turkey are presented.

Table 3. Reliability of the Scales Used in the Study

\begin{tabular}{|l|c|c|}
\hline Scales & Number of & Cronbach's \\
\hline Image of Turkey & 21 & 0.964 \\
\hline Holiday Image & 14 & 0.952 \\
\hline General Image & 7 & 0.919 \\
\hline Turkish Series Attitude Scale & 8 & 0.961 \\
\hline Scale of the Effect of Turkish Series on a visit to Turkey & 8 & 0.977 \\
\hline
\end{tabular}

In Table 3, the reliability values of the Scale of Image of Turkey, the Turkish Series Attitude Scale and the Scale of Effect of Turkish Series on a visit to Turkey are presented. When the results of the reliability test are examined, it is seen that the scales used in the current study are "highly reliable" $(>.80)$.

Table 4. Descriptive Statistics of the Scales Used in the Study

\begin{tabular}{|l|c|c|c|c|c|}
\hline \multicolumn{1}{|c|}{ Scales } & $\mathbf{N}$ & Mean & Std. Deviation & Skewness & Kurtosis \\
\hline Image of Turkey & 500 & 4.1142 & .79341 & -1.431 & 1.430 \\
\hline Holiday Image & 500 & 4.1740 & .80961 & -1.453 & 1.725 \\
\hline General Image & 500 & 3.9946 & .86621 & -.958 & 1.068 \\
\hline Turkish Series Attitude Scale & 500 & 3.5268 & 1.24970 & -.646 & -.537 \\
\hline Scale of the Effect of Turkish & 500 & 3.3055 & 1.33559 & -.241 & -1.198 \\
\hline
\end{tabular}


In Table 4, the descriptive statistics of the Image of Turkey, the Turkish Series Attitude Scale and the Scale of the Effect of Turkish Series to Visit Turkey are shown. According to Tabachnick and Fidell (2013), George and Mallery (2010), if the skewness and Kurtosis values are between +2.0 and -2.0 , it can be argued that the distribution is normal and thus, parametric tests should be used. As the skewness and Kurtosis values of the Scale of Image of Turkey, the Turkish Series Attitude Scale and the Scale of the Effect of Turkish Series of a visit to Turkey were found to be ranging from +2.0 and -2.0 , independent samples t-test, one-way variance analysis, Pearson correlation and regression analyses were used in the current study.

\subsection{Comparison of the Perception of the Image of Turkey and Attitudes towards Turkish Series According to the Demographic Variables}

In this section of the study, the results of t-test conducted to determine whether the perceptions of the image of Turkey and attitudes towards Turkish series vary significantly depending on marital, status, gender, age, education level and income level are presented.

Table 5. Comparison of the Perceptions of the Image of Turkey and Attitudes towards Turkish Series according to Gender

\begin{tabular}{|c|c|c|c|c|c|c|}
\hline Scales & Groups & $\mathbf{N}$ & $\overline{\mathbf{X}}$ & Ss & $\mathbf{T}$ & $\mathbf{P}$ \\
\hline \multirow{2}{*}{ Image of Turkey } & Female & 248 & 4.0611 & .86842 & \multirow{2}{*}{-1.487} & \multirow{2}{*}{.138} \\
\hline & Male & 252 & 4.1665 & .70978 & & \\
\hline \multirow{2}{*}{ Holiday Image } & Female & 248 & 4.1250 & .88504 & \multirow{2}{*}{-1.344} & \multirow{2}{*}{.180} \\
\hline & Male & 252 & 4.2222 & .72635 & & \\
\hline \multirow{2}{*}{ General Image } & Female & 248 & 3.9332 & .93566 & \multirow{2}{*}{-1.574} & \multirow{2}{*}{.116} \\
\hline & Male & 252 & 4.0550 & .78917 & & \\
\hline \multirow{2}{*}{ Turkish Series Attitude Scale } & Female & 248 & 3.3196 & 1.27285 & \multirow{2}{*}{-3.725} & \multirow{2}{*}{.000} \\
\hline & Male & 252 & 3.7307 & 1.19430 & & \\
\hline \multirow{2}{*}{$\begin{array}{l}\text { Scale of the Effect of Turkish } \\
\text { Series on a visit to Turkey }\end{array}$} & Female & 248 & 3.1174 & 1.35253 & \multirow{2}{*}{-3.151} & \multirow{2}{*}{.002} \\
\hline & Male & 252 & 3.4906 & 1.29490 & & \\
\hline
\end{tabular}

In Table 5, the results of the t-test conducted to determine whether the participating Arab tourists' mean scores taken from the Scale of the Image of Turkey, the Turkish Series Attitude Scale and the Scale of the Effect of Turkish Series on a visit to Turkey vary significantly depending on gender are presented. As a result of the t-test, it was concluded that the mean scores taken from the Turkish Series Attitude Scale and the Scale of the Effect of Turkish Series on a visit Turkey varied significantly depending on gender $(p<0.05)$. In other words, the mean scores taken by the male Arab tourists from the Turkish Series Attitude Scale and the Scale of Effect of Turkish Series on a visit to Turkey are significantly higher than those of the female tourists. On the other hand, the mean scores taken from the Scale of the Image of Turkey were found to be not varying significantly depending on gender ( $\mathrm{p}>0.05)$. That is, the female and male Arab tourists' perceptions of the image of Turkey are similar to each other.

Table 6. Comparison of the Perceptions of the Image of Turkey and Attitudes towards Turkish Series according to Marital Status

\begin{tabular}{|c|c|c|c|c|c|c|}
\hline \multirow[b]{2}{*}{ Scales } & \multirow[b]{2}{*}{ Groups } & & \\
\hline & & $\mathbf{N}$ & $\overline{\mathbf{X}}$ & Ss & $\mathbf{T}$ & $\mathbf{P}$ \\
\hline \multirow{2}{*}{ Image of Turkey } & Married & 301 & 4.1362 & .70518 & \multirow{2}{*}{.763} & \multirow{2}{*}{.446} \\
\hline & Single & 199 & 4.0809 & .91167 & & \\
\hline \multirow{2}{*}{ Holiday Image } & Married & 301 & 4.1984 & .72775 & \multirow{2}{*}{.828} & \multirow{2}{*}{.408} \\
\hline & Single & 199 & 4.1371 & .92041 & & \\
\hline \multirow{2}{*}{ General Image } & Married & 301 & 4.0119 & .78692 & \multirow{2}{*}{.549} & \multirow{2}{*}{.583} \\
\hline & Single & 199 & 3.9684 & .97549 & & \\
\hline Turkish Series Attitude Scale & Married & 301 & 3.5681 & 1.15764 & .910 & .363 \\
\hline
\end{tabular}




\begin{tabular}{|c|c|c|c|c|c|c|}
\hline & Single & 199 & 3.4642 & 1.37800 & & \\
\hline \multirow{2}{*}{$\begin{array}{c}\text { Scale of the Effect of Turkish } \\
\text { Series on a Visit to Turkey }\end{array}$} & Married & 301 & 3.2471 & 1.28373 & \multirow{2}{*}{-1.203} & \multirow{2}{*}{.229} \\
\cline { 2 - 6 } & Single & 199 & 3.3938 & 1.40911 & & \\
\hline
\end{tabular}

In Table 6, the results of the t-test conducted to determine whether the participating Arab tourists' mean scores taken from the Scale of the Image of Turkey, the Turkish Series Attitude Scale and the Scale of the Effect of Turkish Series on a visit to Turkey vary significantly depending on marital status are presented. As a result of the t-test, it was concluded that the mean scores taken from the Scale of the Image of Turkey, the Turkish Series Attitude Scale and the Scale of the Effect of Turkish Series on a visit to Turkey did not vary significantly depending on marital status ( $p>0.05)$. That is, the mean scores taken by the married and single Arab tourists from these scales are similar.

Table 7. Comparison of the Perceptions of the Image of Turkey and Attitudes towards Turkish Series according to Whether Following the Actors and Actresses Having Appeared in Turkish Series in Social Media

\begin{tabular}{|c|c|c|c|c|c|c|}
\hline Scales & Groups & $\mathbf{N}$ & $\overline{\mathbf{X}}$ & Ss & $\mathbf{T}$ & $\mathbf{P}$ \\
\hline \multirow{2}{*}{ Image of Turkey } & Yes & 122 & 4.4820 & .52130 & \multirow{2}{*}{6.100} & \multirow{2}{*}{.000} \\
\hline & No & 378 & 3.9955 & .82949 & & \\
\hline \multirow{2}{*}{ Holiday Image } & Yes & 122 & 4.5322 & .51328 & \multirow{2}{*}{5.801} & \multirow[t]{2}{*}{.000} \\
\hline & No & 378 & 4.0584 & .85328 & & \\
\hline \multirow{2}{*}{ General Image } & Yes & 122 & 4.3817 & .64556 & \multirow{2}{*}{5.865} & \multirow[t]{2}{*}{.000} \\
\hline & No & 378 & 3.8696 & .89175 & & \\
\hline \multirow{2}{*}{ Turkish Series Attitude Scale } & Yes & 122 & 4.4027 & .76187 & \multirow{2}{*}{9.699} & \multirow[t]{2}{*}{.000} \\
\hline & No & 378 & 3.2440 & 1.24597 & & \\
\hline \multirow{2}{*}{$\begin{array}{l}\text { Scale of the Effect of Turkish } \\
\text { Series on a Visit to Turkey }\end{array}$} & Yes & 122 & 4.0789 & 1.10388 & \multirow[t]{2}{*}{7.783} & \multirow[t]{2}{*}{.000} \\
\hline & No & 378 & 3.0559 & 1.30917 & & \\
\hline
\end{tabular}

In Table 7, the results of the t-test conducted to determine whether the participating Arab tourists' mean scores taken from the Scale of the Image of Turkey, the Turkish Series Attitude Scale and the Scale of the Effect of Turkish Series on a visit to Turkey vary significantly depending on whether fallowing actors and actresses having appeared in Turkish series in social media are presented. As a result of the t-test, it was concluded that the mean scores taken from the Scale of the Image of Turkey, the Turkish Series Attitude Scale and the Scale of the Effect of Turkish Series on a visit to Turkey varied significantly depending on whether following the actors and actresses having appeared in Turkish series in social media $(\mathrm{p}<0.05)$. In other words, the mean scores taken by the Arab tourists following Turkish actors and actresses in social media from the scales are significantly higher than those of the Arab tourists not following Turkish actors and actresses.

Table 8. Comparison of the Perceptions of the Image of Turkey and Attitudes towards Turkish Series according to Education Level

\begin{tabular}{|c|c|c|c|c|c|c|}
\hline Scales & Groups & $\mathbf{N}$ & $\overline{\mathbf{X}}$ & Ss & $\mathbf{F}$ & $\mathbf{P}$ \\
\hline \multirow{4}{*}{ Image of Turkey } & $\begin{array}{c}\text { Elementary } \\
\text { education and lower }\end{array}$ & 56 & 3.9541 & 1.10063 & \multirow{4}{*}{5.503} & \multirow{4}{*}{.001} \\
\hline & High school & 149 & 4.0668 & .78691 & & \\
\hline & Associate's degree & 100 & 3.9462 & .93421 & & \\
\hline & $\begin{array}{l}\text { Undergraduate and } \\
\text { graduate }\end{array}$ & 195 & 4.2825 & .55299 & & \\
\hline \multirow{4}{*}{ Holiday Image } & $\begin{array}{c}\text { Elementary } \\
\text { education and lower }\end{array}$ & 56 & 4.0344 & 1.17353 & \multirow{4}{*}{5.545} & \multirow{4}{*}{.001} \\
\hline & High school & 149 & 4.1294 & .80386 & & \\
\hline & Associate's degree & 100 & 3.9857 & .93974 & & \\
\hline & $\begin{array}{l}\text { Undergraduate and } \\
\text { graduate }\end{array}$ & 195 & 4.3447 & .54514 & & \\
\hline
\end{tabular}


ÖZDEMIR, Nurcan - Investigation of The Effect of Turkish Tv Series Watched by Arab Tourists on Their Preference for Visiting Turkey

\begin{tabular}{|c|c|c|c|c|c|c|}
\hline \multirow{4}{*}{ General Image } & $\begin{array}{c}\text { Elementary } \\
\text { education and lower }\end{array}$ & 56 & 3.7934 & 1.07075 & \multirow{4}{*}{4.320} & \multirow{4}{*}{.005} \\
\hline & High school & 149 & 3.9415 & .86020 & & \\
\hline & Associate's degree & 100 & 3.8671 & .99954 & & \\
\hline & $\begin{array}{l}\text { Undergraduate and } \\
\text { graduate }\end{array}$ & 195 & 4.1582 & .69387 & & \\
\hline \multirow{4}{*}{$\begin{array}{c}\text { Turkish Series Attitude } \\
\text { Scale }\end{array}$} & $\begin{array}{c}\text { Elementary } \\
\text { education and lower }\end{array}$ & 56 & 3.2254 & 1.45235 & \multirow{4}{*}{2.759} & \multirow{4}{*}{.042} \\
\hline & High school & 149 & 3.5025 & 1.19388 & & \\
\hline & Associate's degree & 100 & 3.3938 & 1.19254 & & \\
\hline & $\begin{array}{l}\text { Undergraduate and } \\
\text { graduate }\end{array}$ & 195 & 3.7000 & 1.24097 & & \\
\hline \multirow{4}{*}{$\begin{array}{c}\text { Scale of the Effect of } \\
\text { Turkish Series on a Visit } \\
\text { to Turkey }\end{array}$} & $\begin{array}{c}\text { Elementary } \\
\text { education and lower }\end{array}$ & 56 & 3.0558 & 1.36513 & \multirow{4}{*}{.819} & \multirow{4}{*}{.484} \\
\hline & High school & 149 & 3.3817 & 1.33398 & & \\
\hline & Associate's degree & 100 & 3.3213 & 1.16535 & & \\
\hline & $\begin{array}{l}\text { Undergraduate and } \\
\text { graduate }\end{array}$ & 195 & 3.3109 & 1.40950 & & \\
\hline
\end{tabular}

In Table 8, the results of the ANOVA test conducted to determine whether the participating Arab tourists' mean scores taken from the Scale of the Image of Turkey, the Turkish Series Attitude Scale and the Scale of the Effect of Turkish Series on a visit to Turkey vary significantly depending on education level are presented. As a result of the ANOVA test, it was concluded that the mean scores taken from the Scale of the Image of Turkey and the Turkish Series Attitude Scale varied significantly depending on education level $(p<0.05)$. In other words, with the increasing education level of the Arab tourists, their perceptions of the image of Turkey and attitudes towards Turkish series also developed positively. On the other hand, the mean scores taken from the Scale of the Effect of Turkish Series on a visit to Turkey were found to be not varying significantly depending on education level $(\mathrm{p}>0.05)$.

Table 9. Comparison of the Perceptions of the Image of Turkey and Attitudes towards Turkish Series according to Age

\begin{tabular}{|c|c|c|c|c|c|c|}
\hline & & & & & & \\
\hline Scales & Groups & $\mathbf{N}$ & $\mathbf{X}$ & Ss & $F$ & $\mathbf{P}$ \\
\hline \multirow{4}{*}{ Image of Turkey } & $18-25$ & 141 & 4.1550 & .79461 & \multirow{4}{*}{0.982} & \multirow{4}{*}{0.401} \\
\hline & $26-35$ & 156 & 4.0259 & .80802 & & \\
\hline & $36-50$ & 119 & 4.1713 & .74868 & & \\
\hline & 51 and older & 84 & 4.1287 & .82524 & & \\
\hline \multirow{4}{*}{ Holiday Image } & $18-25$ & 141 & 4.2305 & .79174 & \multirow{4}{*}{1.009} & \multirow{4}{*}{0.388} \\
\hline & $26-35$ & 156 & 4.0820 & .82851 & & \\
\hline & $36-50$ & 119 & 4.2119 & .78157 & & \\
\hline & 51 and older & 84 & 4.1964 & .84208 & & \\
\hline \multirow{4}{*}{ General Image } & $18-25$ & 141 & 4.0041 & .89832 & \multirow{4}{*}{0.938} & \multirow{4}{*}{0.422} \\
\hline & $26-35$ & 156 & 3.9139 & .86854 & & \\
\hline & $36-50$ & 119 & 4.0900 & .80531 & & \\
\hline & 51 and older & 84 & 3.9932 & .89088 & & \\
\hline \multirow{4}{*}{$\begin{array}{c}\text { Turkish Series Attitude } \\
\text { Scale }\end{array}$} & $18-25$ & 141 & 3.5523 & 1.31476 & \multirow{4}{*}{0.436} & \multirow{4}{*}{0.728} \\
\hline & $26-35$ & 156 & 3.5986 & 1.14775 & & \\
\hline & $36-50$ & 119 & 3.4380 & 1.29821 & & \\
\hline & 51 and older & 84 & 3.4762 & 1.26206 & & \\
\hline \multirow{4}{*}{$\begin{array}{c}\text { Scale of the Effect of } \\
\text { Turkish Series on a Visit } \\
\text { to Turkey }\end{array}$} & $18-25$ & 141 & 3.4051 & 1.33119 & \multirow{4}{*}{0.594} & \multirow{4}{*}{0.619} \\
\hline & $26-35$ & 156 & 3.2091 & 1.35741 & & \\
\hline & $36-50$ & 119 & 3.2763 & 1.28292 & & \\
\hline & 51 and older & 84 & 3.3586 & 1.38418 & & \\
\hline
\end{tabular}


In Table 9, the results of the ANOVA test conducted to determine whether the participating Arab tourists' mean scores taken from the Scale of the Image of Turkey, the Turkish Series Attitude Scale and the Scale of the Effect of Turkish Series on a isit to Turkey vary significantly depending on age are presented. As a result of the ANOVA test, it was concluded that the mean scores taken from the Scale of the Image of Turkey, the Turkish Series Attitude Scale and the Scale of the Effect of Turkish Series on a visit to Turkey did not vary significantly depending on age $(p>0.05)$. In other words, similar perceptions of the image of Turkey and attitudes towards Turkish series are possessed by Arab tourists from different age groups.

Table 10. Comparison of the Perceptions of the Image of Turkey and Attitudes towards Turkish Series according to Income Level

\begin{tabular}{|c|c|c|c|c|c|c|}
\hline Scales & Groups & $\mathbf{N}$ & $\overline{\mathbf{X}}$ & Ss & $\mathbf{F}$ & $\mathbf{P}$ \\
\hline \multirow{4}{*}{ Image of Turkey } & $1000 \$$ and lower & 128 & 4.3534 & .64096 & \multirow{4}{*}{6.357} & \multirow{4}{*}{.000} \\
\hline & $1001-2000 \$$ & 122 & 4.0558 & .93952 & & \\
\hline & $2001-3000 \$$ & 186 & 3.9721 & .83479 & & \\
\hline & $3001 \$$ and higher & 64 & 4.1600 & .48111 & & \\
\hline \multirow{4}{*}{ Holiday Image } & $1000 \$$ and lower & 128 & 4.4146 & .61609 & \multirow{4}{*}{6.650} & \multirow{4}{*}{.000} \\
\hline & $1001-2000 \$$ & 122 & 4.0913 & .95219 & & \\
\hline & $2001-3000 \$$ & 186 & 4.0303 & .86495 & & \\
\hline & $3001 \$$ and higher & 64 & 4.2679 & .53619 & & \\
\hline \multirow{4}{*}{ General Image } & $1000 \$$ and lower & 128 & 4.2310 & .79025 & \multirow{4}{*}{4.968} & \multirow{4}{*}{.002} \\
\hline & $1001-2000 \$$ & 122 & 3.9848 & .99430 & & \\
\hline & $2001-3000 \$$ & 186 & 3.8556 & .88923 & & \\
\hline & $3001 \$$ and higher & 64 & 3.9442 & .53852 & & \\
\hline \multirow{4}{*}{$\begin{array}{c}\text { Turkish Series Attitude } \\
\text { Scale }\end{array}$} & $1000 \$$ and lower & 128 & 3.6553 & 1.25968 & \multirow{4}{*}{1.279} & \multirow{4}{*}{.281} \\
\hline & $1001-2000 \$$ & 122 & 3.4877 & 1.29938 & & \\
\hline & $2001-3000 \$$ & 186 & 3.5457 & 1.18347 & & \\
\hline & $3001 \$$ and higher & 64 & 3.2891 & 1.31174 & & \\
\hline \multirow{4}{*}{$\begin{array}{c}\text { Scale of the Effect of } \\
\text { Turkish Series on a Visit } \\
\text { to Turkey }\end{array}$} & $1000 \$$ and lower & 128 & 3.3721 & 1.50740 & \multirow{4}{*}{1.788} & \multirow{4}{*}{.148} \\
\hline & $1001-2000 \$$ & 122 & 3.3227 & 1.25019 & & \\
\hline & $2001-3000 \$$ & 186 & 3.3710 & 1.26551 & & \\
\hline & $3001 \$$ and higher & 64 & 2.9492 & 1.30089 & & \\
\hline
\end{tabular}

In Table 10, the results of the ANOVA test conducted to determine whether the participating Arab tourists' mean scores taken from the Scale of the Image of Turkey, the Turkish Series Attitude Scale and the Scale of the Effect of Turkish Series on a visit to Turkey vary significantly depending on income level are presented. As a result of the ANOVA test, it was concluded that the mean scores taken from the Scale of the Image of Turkey varied significantly depending on income level $(\mathrm{p}<0.05)$. In other words, the participants with the income level of $1000 \$$ and lower have a significantly more positive perception of the image of Turkey than the other income groups. On the other hand, the mean scores taken from the Turkish Series Attitude Scale and the Scale of the Effect of Turkish Series on a visit to Turkey were found to be not varying significantly depending on income level ( $p>0.05)$. In other words, Arab tourists from different income groups have similar attitudes towards Turkish series.

Table 11. Comparison of the Perceptions of the Image of Turkey and Attitudes towards Turkish Series according to the Frequency of Having Visited Turkey

\begin{tabular}{|c|c|c|c|c|c|c|}
\hline Scales & Groups & $\mathbf{N}$ & $\overline{\mathbf{X}}$ & Ss & $\mathbf{F}$ & $\mathbf{P}$ \\
\hline \multirow{3}{*}{ Image of Turkey } & First time & 222 & 4.1094 & .78404 & \multirow{3}{*}{.186} & \multirow{3}{*}{.906} \\
\hline & Second time & 104 & 4.1635 & .81273 & & \\
\hline & Third time & 84 & 4.0918 & .91136 & & \\
\hline
\end{tabular}


ÖZDEMIR, Nurcan - Investigation of The Effect of Turkish Tv Series Watched by Arab Tourists on Their Preference for Visiting Turkey

\begin{tabular}{|c|c|c|c|c|c|c|}
\hline & Fourth time and more & 90 & 4.0899 & .67824 & & \\
\hline \multirow{4}{*}{ Holiday Image } & First time & 222 & 4.1834 & .78788 & \multirow{4}{*}{.133} & \multirow{4}{*}{.940} \\
\hline & Second time & 104 & 4.1923 & .82978 & & \\
\hline & Third time & 84 & 4.1241 & .95851 & & \\
\hline & Fourth time and more & 90 & 4.1762 & .69064 & & \\
\hline \multirow{4}{*}{ General Image } & First time & 222 & 3.9614 & .89187 & \multirow{4}{*}{.957} & \multirow{4}{*}{.413} \\
\hline & Second time & 104 & 4.1058 & .86839 & & \\
\hline & Third time & 84 & 4.0272 & .90608 & & \\
\hline & Fourth time and more & 90 & 3.9175 & .75440 & & \\
\hline \multirow{4}{*}{$\begin{array}{l}\text { Turkish Series } \\
\text { Attitude Scale }\end{array}$} & First time & 222 & 3.5090 & 1.27039 & \multirow{4}{*}{8.592} & \multirow{4}{*}{.000} \\
\hline & Second time & 104 & 3.5865 & 1.20704 & & \\
\hline & Third time & 84 & 3.0298 & 1.44185 & & \\
\hline & Fourth time and more & 90 & 3.9653 & .83149 & & \\
\hline \multirow{4}{*}{$\begin{array}{c}\text { Scale of the Effect of } \\
\text { Turkish Series on a } \\
\text { Visit to Turkey }\end{array}$} & First time & 222 & 3.3874 & 1.35883 & \multirow{4}{*}{1.665} & \multirow{4}{*}{.174} \\
\hline & Second time & 104 & 3.2308 & 1.49826 & & \\
\hline & Third time & 84 & 3.0506 & 1.24337 & & \\
\hline & Fourth time and more & 90 & 3.4278 & 1.13006 & & \\
\hline
\end{tabular}

In Table 11, the results of the ANOVA test conducted to determine whether the participating Arab tourists' mean scores taken from the Scale of the Image of Turkey, the Turkish Series Attitude Scale and the Scale of the Effect of Turkish Series on a visit to Turkey vary significantly depending on the frequency of having visited Turkey are presented. As a result of the ANOVA test, it was concluded that the mean scores taken from the Turkish Series Attitude Scale varied significantly depending on the frequency of having visited Turkey $(p<0.05)$. In other words, the attitudes of the Arab tourists having visited Turkey fourth time or more have more positive towards Turkish series than the Arab tourists having visited Turkey less. On the other hand, the mean scores taken from the Scale of the Image of Turkey and the Scale of the Effect of Turkish Series on a visit to Turkey were found to be not varying significantly depending on the frequency of having visited Turkey $(p>0.05)$. In other words, the perceptions of the image of Turkey possessed by Arab tourists visiting Turkey in differing frequencies are similar.

Table 12. Comparison of the Perceptions of the Image of Turkey and Attitudes towards Turkish Series according to the Frequency of Following Turkish Series

\begin{tabular}{|c|c|c|c|c|c|c|}
\hline Scales & Groups & $\mathbf{N}$ & $\overline{\mathbf{X}}$ & Ss & $\mathbf{F}$ & $\mathbf{P}$ \\
\hline \multirow{5}{*}{ Image of Turkey } & Never & 150 & 4.0746 & .88055 & \multirow{5}{*}{1.545} & \multirow{5}{*}{.188} \\
\hline & Once a month & 79 & 4.0482 & .71532 & & \\
\hline & Once a week & 147 & 4.0651 & .85729 & & \\
\hline & More than once a week & 59 & 4.2179 & .65895 & & \\
\hline & Everyday & 65 & 4.3026 & .59048 & & \\
\hline \multirow{5}{*}{ Holiday Image } & Never & 150 & 4.1533 & .89687 & \multirow{5}{*}{1.786} & \multirow{5}{*}{.130} \\
\hline & Once a month & 79 & 4.0986 & .75665 & & \\
\hline & Once a week & 147 & 4.1006 & .85921 & & \\
\hline & More than once a week & 59 & 4.2954 & .68144 & & \\
\hline & Everyday & 65 & 4.3692 & .60208 & & \\
\hline \multirow{4}{*}{ General Image } & Never & 150 & 3.9171 & .97542 & \multirow{4}{*}{1.111} & \multirow{4}{*}{.350} \\
\hline & Once a month & 79 & 3.9476 & .74973 & & \\
\hline & Once a week & 147 & 3.9942 & .92247 & & \\
\hline & More than once a week & 59 & 4.0630 & .70250 & & \\
\hline
\end{tabular}




\begin{tabular}{|c|c|c|c|c|c|c|}
\hline & Everyday & 65 & 4.1692 & .71379 & & \\
\hline \multirow{5}{*}{$\begin{array}{l}\text { Turkish Series } \\
\text { Attitude Scale }\end{array}$} & Never & 150 & 2.6175 & 1.27880 & \multirow{5}{*}{45.592} & \multirow{5}{*}{.000} \\
\hline & Once a month & 79 & 3.5443 & .98751 & & \\
\hline & Once a week & 147 & 3.7908 & 1.16171 & & \\
\hline & More than once a week & 59 & 4.2119 & .62812 & & \\
\hline & Everyday & 65 & 4.3846 & .68298 & & \\
\hline \multirow{5}{*}{$\begin{array}{l}\text { Scale of the Effect of } \\
\text { Turkish Series on a } \\
\text { Visit to Turkey }\end{array}$} & Never & 150 & 2.7225 & 1.38081 & \multirow{5}{*}{14.886} & \multirow{5}{*}{.000} \\
\hline & Once a month & 79 & 3.3101 & 1.34553 & & \\
\hline & Once a week & 147 & 3.4039 & 1.25360 & & \\
\hline & More than once a week & 59 & 3.8157 & .94040 & & \\
\hline & Everyday & 65 & 3.9596 & 1.17595 & & \\
\hline
\end{tabular}

In Table 12, the results of the ANOVA test conducted to determine whether the participating Arab tourists' mean scores taken from the Scale of the Image of Turkey, the Turkish Series Attitude Scale and the Scale of the Effect of Turkish Series on a visit to Turkey vary significantly depending on the frequency of following Turkish series are presented. As a result of the ANOVA test, it was concluded that the mean scores taken from the Turkish Series Attitude Scale and the Scale of the Effect of Turkish Series on a visit to Turkey varied significantly depending on the frequency of following Turkish series $(\mathrm{p}<0.05)$. In other words, with the increasing frequency of following Turkish series by the Arab tourists, their attitudes towards Turkish series become more positive. On the other hand, the mean scores taken from the Scale of the Image of Turkey were found to be not varying significantly depending on the frequency of the following Turkish series ( $p>0.05)$. In other words, the images of Turkey of the Arab tourists following Turkish series in differing frequencies are similar.

Table 13. Comparison of the Perceptions of the Image of Turkey and Attitudes towards Turkish Series according to the Frequency of Having Watched Turkish Series Before

\begin{tabular}{|c|c|c|c|c|c|c|}
\hline Scales & Groups & $\mathbf{N}$ & $\overline{\mathbf{X}}$ & Ss & $\mathbf{F}$ & $\mathbf{P}$ \\
\hline \multirow{5}{*}{ Image of Turkey } & None & 121 & 4.0476 & .92406 & \multirow{5}{*}{4.347} & \multirow{5}{*}{.002} \\
\hline & 1 & 91 & 3.8629 & .95449 & & \\
\hline & 2 & 95 & 4.1353 & .74401 & & \\
\hline & 3 & 61 & 4.2576 & .61846 & & \\
\hline & 4 and more & 132 & 4.2670 & .57963 & & \\
\hline \multirow{5}{*}{ Holiday Image } & None & 121 & 4.1482 & .93519 & \multirow{5}{*}{4.938} & \multirow{5}{*}{.001} \\
\hline & 1 & 91 & 3.8838 & .98955 & & \\
\hline & 2 & 95 & 4.1647 & .74770 & & \\
\hline & 3 & 61 & 4.3232 & .61301 & & \\
\hline & 4 and more & 132 & 4.3355 & .59480 & & \\
\hline \multirow{5}{*}{ General Image } & None & 121 & 3.8465 & 1.03282 & \multirow{5}{*}{3.225} & \multirow{5}{*}{.012} \\
\hline & 1 & 91 & 3.8210 & .95869 & & \\
\hline & 2 & 95 & 4.0767 & .82509 & & \\
\hline & 3 & 61 & 4.1265 & .72002 & & \\
\hline & 4 and more & 132 & 4.1299 & .67156 & & \\
\hline \multirow{5}{*}{$\begin{array}{l}\text { Turkish Series } \\
\text { Attitude Scale }\end{array}$} & None & 121 & 2.4153 & 1.26432 & \multirow{5}{*}{55.772} & \multirow{5}{*}{.000} \\
\hline & 1 & 91 & 3.4299 & 1.22704 & & \\
\hline & 2 & 95 & 3.6566 & 1.11117 & & \\
\hline & 3 & 61 & 4.0840 & .77752 & & \\
\hline & 4 and more & 132 & 4.2614 & .66278 & & \\
\hline \multirow{5}{*}{$\begin{array}{c}\text { Scale of the Effect of } \\
\text { Turkish Series on a } \\
\text { Visit to Turkey }\end{array}$} & None & 121 & 2.5589 & 1.35833 & \multirow{5}{*}{16.891} & \multirow{5}{*}{.000} \\
\hline & 1 & 91 & 3.2500 & 1.35913 & & \\
\hline & 2 & 95 & 3.4079 & 1.15823 & & \\
\hline & 3 & 61 & 3.7910 & 1.07256 & & \\
\hline & 4 and more & 132 & 3.7301 & 1.23694 & & \\
\hline
\end{tabular}


In Table 13, the results of the ANOVA test conducted to determine whether the participating Arab tourists' mean scores taken from the Scale of the Image of Turkey, the Turkish Series Attitude Scale and the Scale of the Effect of Turkish Series on a visit to Turkey vary significantly depending on the frequency of having watched Turkish series are presented. As a result of the ANOVA test, it was concluded that the mean scores taken from the Scale of Image of Turkey, the Turkish Series Attitude Scale, the Scale of the Effect of Turkish Series on a visit to Turkey varied significantly depending on the frequency of having watched Turkish series $(p<0.05)$. In other words, with increasing frequency of watching Turkish series, the Arab tourists' perceptions of the image of Turkey and attitudes towards Turkish series also improved.

\subsection{Interactions between the Scale of the Image of Turkey, the Turkish Series Attitude Scale and the Scale of the Effect of Turkish Series on a visit to Turkey}

In this section of the study, the results of the regression and correlation analyses conducted to reveal the interactions between the Scale of the Image of Turkey, the Turkish Series Attitude Scale and the Scale of the Effect of Turkish Series on a visit to Turkey are presented.

Table 14. Correlations between the Scale of the Image of Turkey, the Turkish Series Attitude Scale and the Scale of the Effect of the Turkish Series on a Visit to Turkey

\begin{tabular}{|l|c|c|c|c|c|}
\hline & Image of & Holiday & General Image & Turkish Series & Scale of the \\
\hline Image of Turkey & 1 & & & & \\
\hline Holiday Image & $.978^{* *}$ & 1 & & & \\
\hline General Image & $.920^{* *}$ & $.818^{* *}$ & 1 & & \\
\hline Turkish Series & $.408^{* *}$ & $.375^{* *}$ & $.418^{* *}$ & 1 & \\
\hline Scale of the Turkish & $.448^{* *}$ & $.388^{* *}$ & $.506^{* *}$ & $.582^{* *}$ & 1 \\
\hline
\end{tabular}

In Table 14, the results of the Pearson correlation analysis conducted to determine the correlations between the Scale of the Image of Turkey, the Turkish Series Attitude Scale and the Scale of the Effect of Turkish Series on a visit to Turkey are presented. As a result of the analysis, it was concluded that there is a positive and significant correlation between the image of Turkey, attitudes towards Turkish series and the effect of Turkish series on a visit to Turkey $(\mathrm{p}<0.05)$. In other words, with improving attitudes towards Turkish series, the image of Turkey and the effect of Turkish series on a visit to Turkey also improve.

Table 15. Effect of Turkish Series on the Image of Turkey

\begin{tabular}{|c|c|c|c|c|c|}
\hline \multirow{2}{*}{$\begin{array}{c}\text { Model } \\
\text { Dependent Variable: Image } \\
\text { of Turkey }\end{array}$} & \multicolumn{2}{|c|}{$\begin{array}{l}\text { Non-standardized } \\
\text { Coefficients }\end{array}$} & \multirow{2}{*}{$\begin{array}{c}\text { Standardized } \\
\text { Coefficients } \\
\text { Beta }\end{array}$} & \multirow{2}{*}{$\mathbf{T}$} & \multirow{2}{*}{ Sig. } \\
\hline & B & $\begin{array}{c}\text { Std. } \\
\text { Deviation }\end{array}$ & & & \\
\hline (Constant) & 3.234 & .085 & & 38.126 & .000 \\
\hline $\begin{array}{c}\text { Attitudes towards Turkish } \\
\text { Series }\end{array}$ & .266 & .024 & .448 & 11.188 & .000 \\
\hline Sig. & \multicolumn{5}{|c|}{0.000} \\
\hline F & \multicolumn{5}{|c|}{125.167} \\
\hline $\mathrm{R}^{2}$ & \multicolumn{5}{|c|}{0.199} \\
\hline
\end{tabular}

With the regression analysis shown in Table 15, the effect of the attitudes towards Turkish series on the image of Turkey was revealed. As a result of the regression analysis, the attitudes towards Turkish series were found to have a significant effect on the image of Turkey. In other words, with improving attitudes towards Turkish series, 
the image of Turkey also improves. $19.9 \%$ of the total variance in the image of Turkey is explained by the attitudes towards Turkish series.

Table 16. Effect of Turkish Series on Holiday Image

\begin{tabular}{|c|c|c|c|c|c|}
\hline \multirow{2}{*}{$\begin{array}{c}\text { Model } \\
\text { Dependent Variable: } \\
\text { Holiday Image }\end{array}$} & \multicolumn{2}{|c|}{$\begin{array}{l}\text { Non-standardized } \\
\text { Coefficients }\end{array}$} & \multirow{2}{*}{$\begin{array}{c}\begin{array}{c}\text { Standardized } \\
\text { Coefficients }\end{array} \\
\text { Beta }\end{array}$} & \multirow{2}{*}{$\mathbf{T}$} & \multirow{2}{*}{ Sig. } \\
\hline & B & $\begin{array}{c}\text { Std. } \\
\text { Deviation }\end{array}$ & & & \\
\hline (Constant) & 3.396 & .089 & & 38.060 & .000 \\
\hline $\begin{array}{c}\text { Attitudes towards Turkish } \\
\text { Series }\end{array}$ & .235 & .025 & .388 & 9.395 & .000 \\
\hline Sig. & \multicolumn{5}{|c|}{0.000} \\
\hline $\mathrm{F}$ & \multicolumn{5}{|c|}{88.272} \\
\hline $\mathrm{R}^{2}$ & \multicolumn{5}{|c|}{0.149} \\
\hline
\end{tabular}

With the regression analysis shown in Table 16, the effect of the attitudes towards Turkish series on the holiday image was revealed. As a result of the regression analysis, the attitudes towards Turkish series were found to have a significant effect on the holiday image. In other words, with improving attitudes towards Turkish series, the holiday image also improves. $14.9 \%$ of the total variance in the holiday image is explained by the attitudes towards Turkish series.

Table 17. Effect of Turkish Series on General Image

\begin{tabular}{|c|c|c|c|c|c|}
\hline $\begin{array}{c}\text { Model } \\
\begin{array}{c}\text { Dependent Variable: } \\
\text { General Image }\end{array}\end{array}$ & \multicolumn{2}{|c|}{$\begin{array}{c}\text { Non-standardized } \\
\text { Coefficients }\end{array}$} & $\begin{array}{c}\text { Standardized } \\
\text { Coefficients }\end{array}$ & \multirow{2}{*}{ T } & Sig. \\
\cline { 2 - 5 } & $\mathbf{B}$ & $\begin{array}{c}\text { Std. } \\
\text { Deviation }\end{array}$ & Beta & & \\
\hline (Constant) & 2.909 & .089 & & 32.563 & .000 \\
\hline $\begin{array}{c}\text { Attitudes towards Turkish } \\
\text { Series }\end{array}$ & .328 & .025 & .506 & 13.097 & .000 \\
\hline Sig. & \multicolumn{5}{|c}{0.000} \\
\hline F & \multicolumn{5}{|c}{171.532} \\
\hline $\mathrm{R}^{2}$ & \multicolumn{5}{|c}{0.255} \\
\hline
\end{tabular}

With the regression analysis shown in Table 17, the effect of the attitudes towards Turkish series on the general image was revealed. As a result of the regression analysis, the attitudes towards Turkish series were found to have a significant effect on the general image. In other words, with the improving attitudes towards Turkish series, the general image also improves. $26.5 \%$ of the total variance in the general image is explained by the attitudes towards Turkish series.

Table 18. Effect of Turkish Series on a Visit to Turkey

\begin{tabular}{|c|c|c|c|c|c|}
\hline \multirow{2}{*}{$\begin{array}{c}\text { Model } \\
\text { Dependent Variable: } \\
\text { Attitudes towards Turkish } \\
\text { Series }\end{array}$} & \multicolumn{2}{|c|}{$\begin{array}{c}\text { Non-standardized } \\
\text { Coefficients }\end{array}$} & \multirow{2}{*}{$\begin{array}{c}\begin{array}{c}\text { Standardized } \\
\text { Coefficients }\end{array} \\
\text { Beta } \\
\end{array}$} & \multirow[b]{2}{*}{$\mathbf{T}$} & \multirow[b]{2}{*}{ Sig. } \\
\hline & B & $\begin{array}{c}\text { Std. } \\
\text { Deviation }\end{array}$ & & & \\
\hline (Constant) & 1.728 & .122 & & 14.211 & .000 \\
\hline Effect of Turkish Series & .544 & .034 & .582 & 15.957 & .000 \\
\hline $\begin{array}{l}\text { Sig. } \\
\text { Si }\end{array}$ & \multicolumn{5}{|c|}{0.000} \\
\hline $\mathrm{F}$ & \multicolumn{5}{|c|}{254.632} \\
\hline $\mathrm{R}^{2}$ & \multicolumn{5}{|c|}{0.337} \\
\hline
\end{tabular}

With the regression analysis shown in Table 18, the effect of Turkish series on a visit to Turkey was revealed. As a result of the regression analysis, Turkish series were found to have a significant effect on a visit to Turkey. In 
other words, with improving attitudes towards Turkish series, the tendency to visit Turkey also increases. 33.7\% of the total variance in the intention to visit Turkey is explained by the attitudes towards Turkish series.

\section{RESULTS AND SUGGESTIONS}

Turkish series which have a large audience in the four corners of the world, from the Middle East to the Balkans, from Europe to Latin America and to Central Asia is one of Turkey's most influential soft power tools. Turkey ranks second after America in exporting series to the world. It is aimed to increase the annual income obtained from the export of TV series to 156 countries to 1 billion dollars in 2023. Export of Turkish series is an issue that includes many dynamics. Along with the series that are exported, many intangible and tangible values such as Turkish culture, customs, traditions, language, art, music, food, fashion, city, region, architecture, and local brands are also exported. In this way, local productions turn into the most important means of exporting Turkish culture. The return of cultural export, which is applied as the marketing of social life style and cultural accumulation, is more profitable and permanent in the long term than the marketing of industrial products. Turkish TV series have increased the interest in Turkish brands and thus allowed Turkish companies to penetrate into the markets of the countries where they have been broadcast more easily and they and led to increasing admiration for Turkey and this admiration has naturally turned into a desire to visit the country. Especially middle and upper-class tourists coming from oil-rich countries in the Arab geography have made important contributions to the Turkish economy with their high spending capacities.

In the current study, the attitudes of Arab people towards Turkish series, their perceptions of the image of Turkey and the effect of these attitudes and perceptions on a visit to Turkey were investigated. Moreover, it was explored whether Arab tourists' attitudes towards Turkish series and perceptions of the image of Turkey varied significantly depending on some demographic variables such as gender, age, income level, education level and marital status. To this end, a questionnaire was administered to 500 Arab tourists visiting Turkey.

As a result of the analyses conducted, it was concluded that the mean scores taken from the Turkish Series Attitude Scale and the Scale of the Effect of Turkish Series on a visit to Turkey varied significantly depending on gender. In other words, the male Arab tourists have more positive attitudes towards Turkish series and a greater tendency to visit Turkey than the female Arab tourists.

Moreover, the mean scores taken from the Turkish Series Attitude Scale and the Scale of the Effect of Turkish Series on a visit to Turkey were found to be varying significantly depending on whether following Turkish actors and actresses in social media. In other words, the mean scores of the Arab tourists following Turkish actors and actresses in social media taken from the Scale of the Image of Turkey, the Turkish Series Attitude Scale and the Scale of the Effect of Turkish Series on a visit to Turkey are significantly higher than those of the Arab tourists not following them in social media. In addition to this, it was also found that with the increasing level of education of the Arab tourists, their attitudes towards Turkish series and image of Turkey were found to be improving.

Another important finding of the study is that there is a positive and significant correlation between the attitudes towards Turkish series and the image of Turkey and the effect of Turkish series on a visit to Turkey. In other words, watching Turkish series positively affects Arab tourists' intention to visit Turkey. Thus, it can be argued that with the improving attitudes of Arab tourists towards Turkish series, their image of Turkey improves and their intention of visiting the country increases as well.

In this context, TV series that will contribute to the promotion of national culture should be supported, the success already achieved should be preserved, the international competitiveness of the cinema sector should be increased, and research that will contribute to these issues should be conducted.

In the current study, the effect of Arab people's attitudes towards Turkish series and perceptions of the image of Turkey on their intention to visit Turkey was revealed. In this context, one limitation of the study is that it was conducted on 500 Arab tourists visiting Antalya and İstanbul. Moreover, time, method and calculation-related mistakes that can occur in any questionnaire study may have occurred in the current study. Similar research can be conducted on different samples and then the results can be compared with the results of the current study. 


\section{REFERENCES}

AKDU, U., AKIN, M. A. (2016, Ağustos), "Film ve Dizilerin Destinasyon Tercihine Etkileri" Uluslararası Sosyal Araştırmalar Dergisi, 9(45), 1042-1052.

AKOVA, S. (2014), “Türk dizilerinin Balkanlar'daki etkileri (Sirbistan, Karadağ ve Bosna Hersek Örneklemi) Kültürlerarası iletişim bağlamında; Türk dizilerinin fahri elçiler olmaları söyleminden hareketle, Türk ve Balkan toplumlarının, kültürel ve tarihi benzerliklerini okumak" (Yayımlanmamış Doktora Tezi). Maltepe Üniversitesi, Sosyal Bilimler Enstitüsü, İstanbul.

AKŞEN, D. (2016), “Arap Coğrafyasında Türk Dizileri Ve İzlenme Nedenleri”, Yüksek Lisans Tezi. Çanakkale. T.C. Çanakkale Onsekiz Mart Üniversitesi Sosyal Bilimler Enstitüsü Uluslarası İlişkiler Anabilim Dalı Ortadoğu Araştırmaları.

ALANKUŞ, S., YANARDAĞOĞLU, E. (2016), “Vacillation in Turkey's Popular Global TV Exports: Toward A More Complex Understanding of Distribution", International Journal of Communication, 10(1), 3615-3631.

ALIYEV, A. (2014), "Türkiye İmajının Turizm Talebine Etkisi: Arap Ülkelerinden Gelen Turistler Üzerine Bir Araştırma”, Yayınlanmamış Yüksek Lisans Tezi. Ankara: Gazi Üniversitesi Eğitim Bilimleri Enstitüsü.

BALLİ, F., BALLİ, H. O., CEBECİ, K. (2013), "Impacts of Exported Turkish Soap Operas and Visa-Free Entry on Inbound Tourism to Turkey", Tourism Management, 37, 186-192.

BOUKARI, Z. (Matar, 2017), VEYSELLER, F. VE IYYİGÜN, N. Ö. (2019), “Türk Televizyon Dizilerinin Destinasyon Tercihi Açısından Değerlendirilmesi: Ortadoğulu turistler", İstanbul Ticaret Üniversitesi Sosyal Bilimler Dergisi, 18(35), 367-382.

BRLJAVAC, B. (2011), "Turkey Entering The European Union Through The Balkan Doors: In the Style of a Great Power?" Middle East Studies Online Journal, 6(3), 82-92.

BUDAK, M. M. (2019), “Türkiye’nin Ortadoğu'da Kamu Diplomasisi Tecrübesi”, Ortadoğu Etütleri, 11(1), 142-169.

DENIZ, Ç. A. (2010), “Gümüş Dizisinin Arap Kamuoyuna Etkileri Bir Sosyal Medya İncelemesi”, Uşak Üniversitesi Sosyal Bilimler Dergisi, 3(1), 50-67.

DİNÇER, O. B., KUTLAY, M. (2012), “Türkiye'nin Ortadoğu'daki güç kapasitesi: Mümkünün sınırları”, Ankara: USAK.

GEÇER, E. (2015, 06 30), “Türk Dizileri Üzerine Kültürel ve İdeolojik Bır Değerlendirme: Made in Turkey”, Mütefekkir, 2(3), 39-56.

KANTARCI, K., BASARAN, M., ÖZYURT, P. (2015), “The Effect of Turkish TV Series on Inbound Tourism of Turkey: A Case of Saudi Arabia and Bulgaria", International Scientific Conference.

MATAR, A. (2017), "Tourist Destination Marketing: The Influence of Turkish Drama on Arab Tourists", Master's Thesis. İstanbul: The Republic of Turkey Bahçeşehir University.

MILLER, D. (1995), "The Consumption of Soap Operas: The Young and the Restless and Mass Consumption in Trinidad”, Editör R.C. Allen, Soap Operas Around The World (ss. 213-233). London: Routledge.

NUROĞLU, E. (2013), “Dizi Turizmi: Orta Doğu ve Balkanlar'dan Gelen Turistlerin Türkiye'yi Ziyaret Kararında Türk Dizileri Ne Kadar Etkili?”, 5. İstanbul Uluslararası İktisatçılar Zirvesi, 1-12.

ÖKMEN, Y. E., GÖKSU, O. (2019), “Kültürel Diplomasi Bağlamında Türk Dizilerinin İhracatı ve Kültür Aktarımına Katkısı: Diriliş Ertığrul Örneği”, Editör O. Göksu, Kamu diplomasisinde yeni yönelimler (ss. 247291). Konya: Literatürk academia Yayınları.

ÖKTEM, K. (2010), “Projecting Power: Turkish TV Series and Their External Effects. Turkey's Foreign Policy in A Changing World: Old Alignments And New Neighbourhoods", International Conference, Oxford.

ÖRGÜN, E. (2012), "Filmlerin ve Televizyon Dizilerinin Destinasyon Seçimine Etkisi”, Yüksek Lisans Tezi, Ankara: T.C. Gazi Ünivetsitesi.

ÖZTÜRK, M., ATIK, A. (2016), "Ulusal Pazardan Küresel Pazarlara Uzanan Süreçte Türk Dizilerinin Gelişimi”, Maltepe Üniversitesi İletişim Fakültesi Dergisi, 3(2), 66-82. 
PERVAN, S. J., MARTIN, B. A. S. (2002), "Product Placement in US and New Zealand Television Soap Operas: An Exploratory Study”, Journal of Marketing Communications, 8(2), 101-113.

PINTO (2012). İzzet Pinto, Diziler yeniçerileri geçti. [Çevrimiçi] http://www.hurriyet.com.tr /diziler-yenicerilerigecti-22261153 [Erişim Tarihi: 04/07/2020].

TEMINA, A. (2019), “Cezayir'de İzlenen Türk Dizilerinin Türkiye Algısına Etkisi”, Antalya: Akdeniz Üniversitesi Sosyal Bilimler Enstitüsü.

TÜRKIYE OTELCILLER BİRLİĞİ. (2018). 2018 yll faaliyet raporu. İstanbul: TÜROB.

YANARDAĞOĞLU, M., KARAM, I. (2013), "The Fever That Hit Arab Satellite Television: Audience Perceptions of Turksih TV Series", Identities, 20(5), 561-579.

YEŞIL, B. (2015), "Transnationalization of Turkish Dramas: Exploring the Convergence of Local and Global Market Imperatives" Global Media and Communication, 11(1), 43-60.

YILMAZ, B. (2014), “2000’li yıllarda Türk dizi sektörünün durumu”, Yüksek lisans tTezi. Kadir Has Üniversitesi.

YİGiT, A. (2013), "Turkish Drama in the Middle East: Secularism and Cultural Influence", IEMed, Mediterranean Yearbook's, 291-294.

YORUK, Z., VATIKIOTIS, P. (2013), "Soft Power Or İllusion Of Hegemony: The Case Of The Turkish Soap Opera "Colonialism", International Journal of Communication, 7(1), 2361-2385.

ZAVALSIZ, Y. S., SOYDAŞ-DAĞCI, Y. (2019), “Televizyon Dizilerinin Toplum Üzerindeki Etkisi (Karabük Örneği)", Çukurova Üniversitesi İlahiyat Fakültesi Dergisi, 19(1), 185-201. 


\section{APPENDIX}

\section{INVESTIGATION OF THE EFFECT OF TURKISH SERIES ON ARAB TOURISTS' PREFERENCE FOR VISITING TURKEY \\ دراسة أثر المسلسلات التركية على قدوم السياح العرب الى تركيا}

The current survey is conducted within the context of a master's thesis. Your responses will only be used for scientific purposes not for any other purpose. We thank you for your participation.

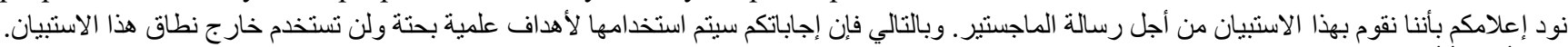

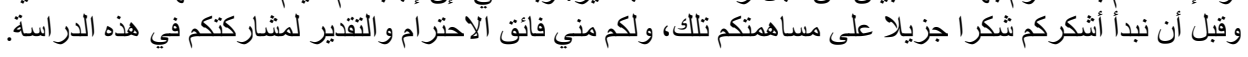

1. Gender: ( ) Female ( ) Male

2. Age:
أنثى ( )
ذكر ( )

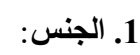

3. Marital status: ( ) Married ( ) Single

4. Education level: ( ) Elementary education and lower ( ) High school

3 Undergraduate degree ( ) Graduate degree
ماجستير ( ) ماجن ( )
جامعة ( )
( ) مeft

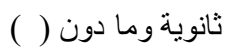
4. المستوى التعليمي: إبتدائي ( )

5. The total income of your family in $\$$

5. 5جموع الاخل العائلي شهريا بقيمة الدولار

6. What is your frequency of having visited Turkey before?
( ) First time
( ) Second time
( ) Third time
( ) Fourth time and more

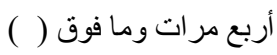

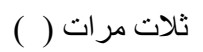

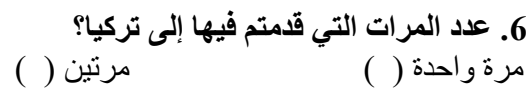

7. What is your frequency of following Turkish series?
( ) Never
( ) Once a month
( ) Once a week
( ) More than once a week
( ) Everyday

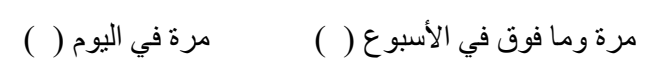

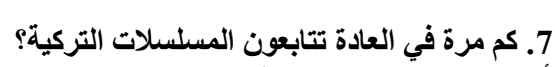

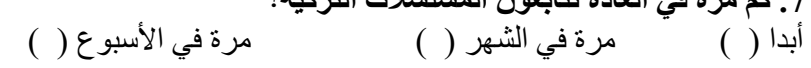

8. Do you follow the actors and actresses having appeared in Turkish series in social media?
( ) Yes (Who do you follow

( ) No

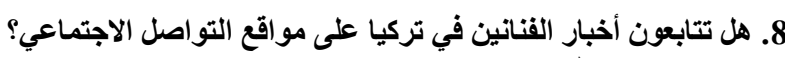
نعم ( ) ) (اذا كان الجواب نعم، فمن تتابعون؟.

9. Have many Turkish series have you watched from the beginning to the end so far?
( ) None
( ) 1
( ) 2
( ) 3
( ) 4 and more
أربع وما فوق ( )
ثلاثة ( )
ا اثنين ( )

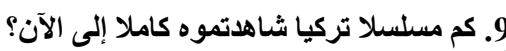
واحد ( ) الآن

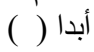

10. Which country did you come from?

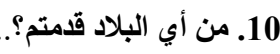

11. Why did you come? (You can mark more than one option)
( )Touristic
( ) Business
( ) Education
( ) Others
11. سبب القدوم؟ (يمكنكم تظليل أكثر من خيار) ( ) ( )
أسباب أخرى ( )

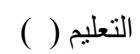
( ) العمل ( ) من ()

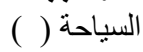

12. What are the Turkish series you like the most? 
INVESTIGATION OF THE EFFECT OF TURKISH SERIES ON ARAB TOURISTS' PREFERENCE FOR VISITING TURKEY

دراسة أثر المسلسلات التركية على قدوم السياح العرب الى تركيا

\begin{tabular}{|c|c|c|c|c|c|}
\hline 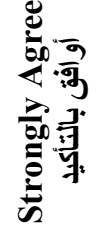 & 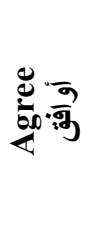 & 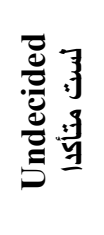 & 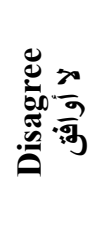 & 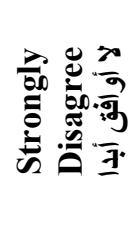 & $\begin{array}{c}\text { Turkish Series Attitude Scale } \\
\text { درجة التَعلقَ بالمسلسلات التركية }\end{array}$ \\
\hline & & & & & I like Turkish series. \\
\hline & & & & & 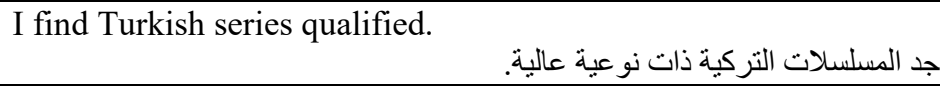 \\
\hline & & & & & 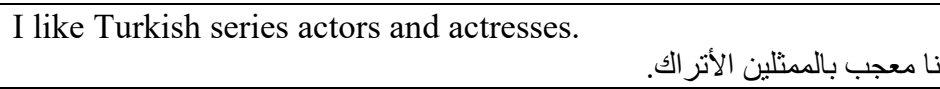 \\
\hline & & & & & 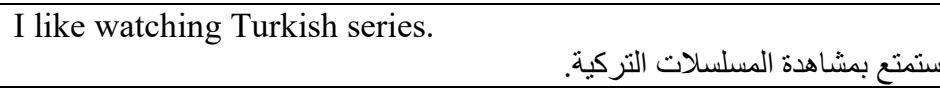 \\
\hline & & & & & 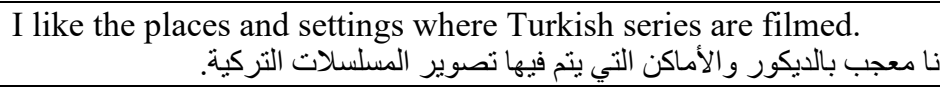 \\
\hline & & & & & 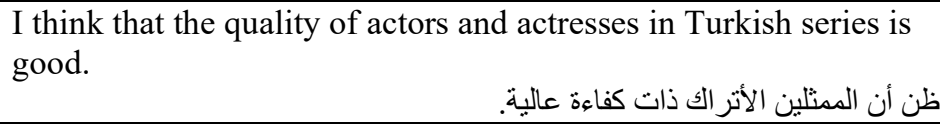 \\
\hline & & & & & 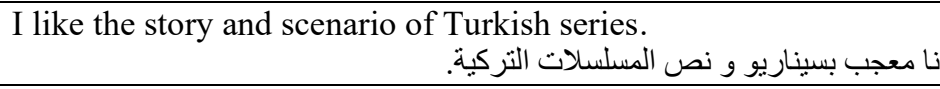 \\
\hline & & & & & 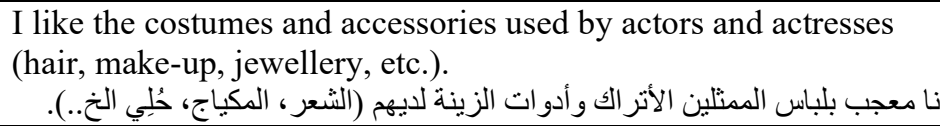 \\
\hline
\end{tabular}


INVESTIGATION OF THE EFFECT OF TURKISH SERIES ON ARAB TOURISTS' PREFERENCE FOR VISITING TURKEY

دراسة أثر المسلسلات التركية على قدوم السياح العرب الى تركيا

\begin{tabular}{|c|c|c|c|c|c|}
\hline 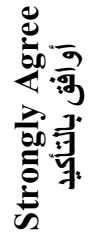 & 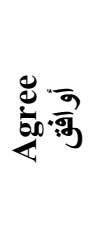 & 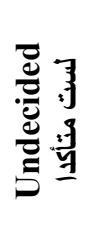 & 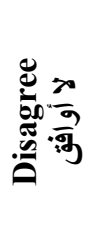 & 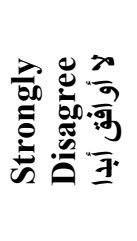 & $\begin{array}{l}\text { Scale of the Image of Turkey } \\
\text { مقدار الإنطباع الذهني عن تركيا }\end{array}$ \\
\hline & & & & & Turkey is a nice country to have a holiday. \\
\hline & & & & & 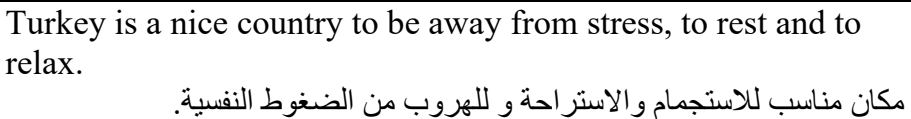 \\
\hline & & & & & 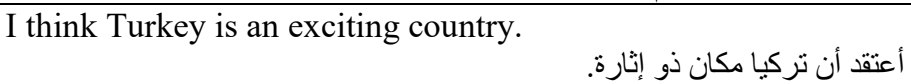 \\
\hline & & & & & 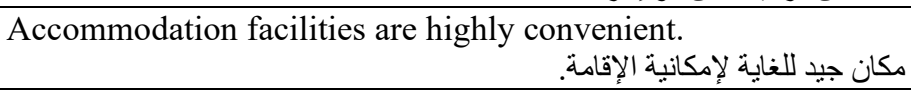 \\
\hline & & & & & $\begin{array}{ll}\text { Tourism infrastructure is sufficient. } & \text { البنية التحتية السياحية فيها كافية. }\end{array}$ \\
\hline & & & & & $\begin{array}{ll}\text { Turkish people are friendly and sincere. } \\
\end{array}$ \\
\hline & & & & & 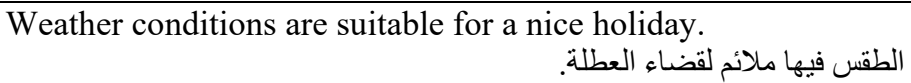 \\
\hline & & & & & 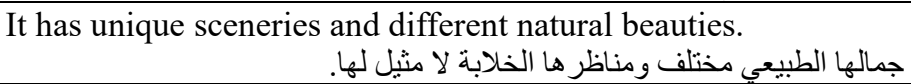 \\
\hline & & & & & $\begin{array}{ll}\text { Its local food is delicious. } & \text { أطعمتها المحلية لذيذة. }\end{array}$ \\
\hline & & & & & $\begin{array}{l}\text { It is a nice place to explore a new culture. } \\
\text { مكان جميل للكثف عن ثقافة مختلفة. }\end{array}$ \\
\hline & & & & & 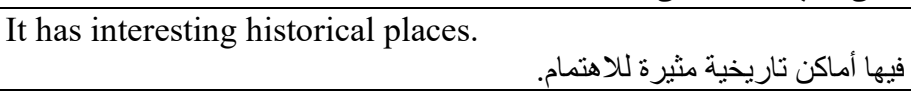 \\
\hline & & & & & It offers attractive shopping opportunities. إمكانيات التسوق لديها جذابة. \\
\hline & & & & & 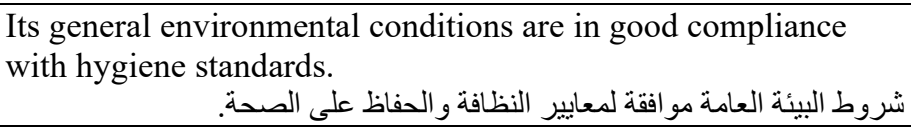 \\
\hline & & & & & 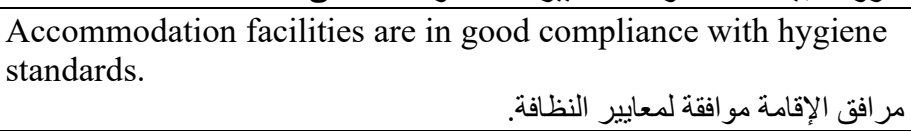 \\
\hline & & & & & It has a positive image. تُكوّن عندك انطباعات ذهنية إيجابية. \\
\hline & & & & & It is respectful to human rights. \\
\hline & & & & & تتميز باستتباب الأمن فيها. \\
\hline & & & & & It is a secular country. \\
\hline & & & & & It is a country of tolerance. \\
\hline & & & & & 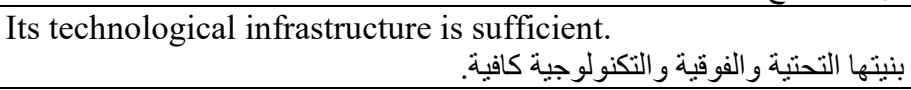 \\
\hline & & & & & $\begin{array}{l}\text { It is a modern country. } \\
\end{array}$ \\
\hline
\end{tabular}




\section{INVESTIGATION OF THE EFFECT OF TURKISH SERIES ON ARAB TOURISTS' PREFERENCE FOR VISITING TURKEY}

دراسة أثر المسلسلات التركية على قدوم السياح العرب الى تركيا

\begin{tabular}{|c|c|c|c|c|c|}
\hline 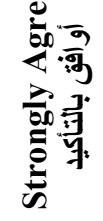 & 这. & 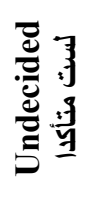 & 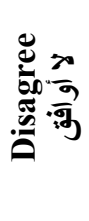 & 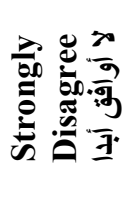 & $\begin{array}{c}\text { Scale of Effect of Turkish Series } \\
\text { درجة تأثير المسلسلات التركية }\end{array}$ \\
\hline & & & & & $\begin{array}{l}\text { The fact that I follow Turkish series is influential on my visit to } \\
\text { the country. } \\
\text { متابعتى للمسلسلات التركية أثرت على زيارتى لتركيا. }\end{array}$ \\
\hline & & & & & 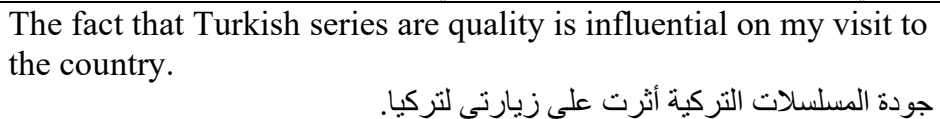 \\
\hline & & & & & $\begin{array}{l}\text { The fact that I like Turkish series is influential on my visit to } \\
\text { Turkey. } \\
\text { شغفي بالمسلسلات التركية أثر على زيارنى لتركيا. }\end{array}$ \\
\hline & & & & & 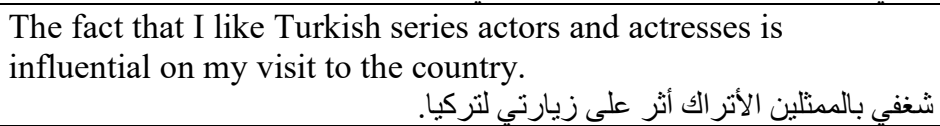 \\
\hline & & & & & 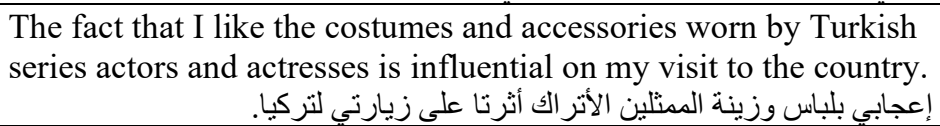 \\
\hline & & & & & 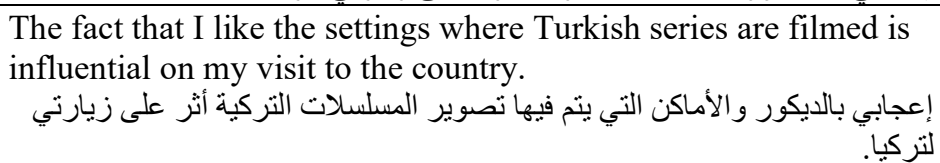 \\
\hline & & & & & 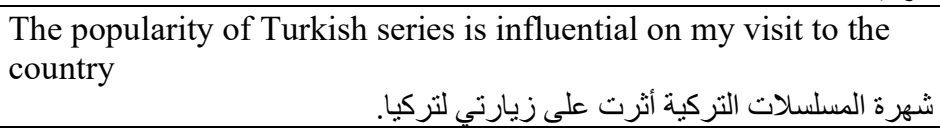 \\
\hline & & & & & 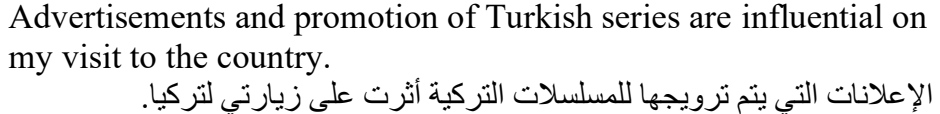 \\
\hline
\end{tabular}

